\title{
Genetic analysis of Aegilops tauschii-derived seedling resistance to leaf rust in synthetic hexaploid wheat
}

\author{
Volker Mohler $^{1}$ (I) $\cdot$ Michael Schmolke ${ }^{2}$ Friedrich J. Zeller ${ }^{2}$ - Sai L. K. Hsam² \\ Received: 5 November 2019 / Revised: 19 December 2019 / Accepted: 8 January 2020 / Published online: 24 January 2020 \\ (C) The Author(s) 2020
}

\begin{abstract}
Seedling resistance to leaf rust available in the synthetic hexaploid wheat line Syn137 was characterised by means of cytogenetic and linkage mapping. Monosomic analysis located a single dominant gene for leaf rust resistance on chromosome 5D. Molecular mapping not only confirmed this location but also positioned the gene to the distal part of the long arm of chromosome 5D. A test of allelism showed that the gene, tentatively named LrSyn 137, is independent but closely linked to Lr1. It appears that Syn137 is occasionally heterogeneous for $\mathrm{Lr} 1$ since the analysis of the $\mathrm{Lr} 1$-specific marker RGA567-5 in the genetic mapping population indicated the presence of $\operatorname{Lr} 1$. Syn 137 represents another source of genetic variation that can be useful for the diversification of leaf rust resistance in wheat cultivars.
\end{abstract}

Keywords Disease resistance $\cdot$ Molecular mapping $\cdot$ Monosomic analysis $\cdot$ Puccinia triticina $\cdot$ Triticum aestivum

\section{Introduction}

Leaf rust, caused by the fungus Puccinia triticina $(P t)$, is a foliar wheat disease of global significance. The most effective, economical, and environmentally sound means of controlling this disease is the deployment of resistant wheat cultivars. To date, formally designated leaf rust resistance genes have been catalogued at 76 loci (Lr1-Lr79; McIntosh et al. 2013, 2017; Qureshi et al. 2018). The release of cultivars with resistance based upon single major resistance genes leads to the emergence of pathotypes with matching virulence. Hence, the identification of new sources of resistance to leaf rust becomes an ongoing process to maintain resistance diversity in released cultivars. Various strategies for prolonging resistance in commercial cultivars have been proposed. These include the

Communicated by: Barbara Naganowska

Volker Mohler

volker.mohler@1fl.bayern.de

1 Bayerische Landesanstalt für Landwirtschaft (LfL), Institut für Pflanzenbau und Pflanzenzüchtung (IPZ), Am Gereuth 8, 85354 Freising, Germany

2 Plant Breeding, Centre for Food and Life Sciences Weihenstephan, Technical University of Munich, Liesel-Beckmann-Str. 2, 85354 Freising, Germany deployment of different combinations of major and/or adult plant resistance genes within single cultivars, referred to as gene pyramiding or gene stacking, or between different plants within the wheat crop such as in agronomically similar cultivar mixtures or genetically related multiline varieties (Burdon et al. 2014).

Synthetic hexaploid wheat lines $(2 n=6 x=42$, AABBDD sub-genomes) produced as chromosomally doubled hybrids (via colchicine treatment) between Triticum turgidum $(2 n=$ $4 x=28$, AABB sub-genomes) and Aegilops tauschii $(2 n=$ $2 x=14$, DD genome) are important genetic resources enabling the direct exploitation of genetic variation present in both the AABB sub-genome progenitors and close relatives and the $\mathrm{D}$ genome progenitor of cultivated wheat. Of the currently named leaf rust resistance genes in wheat, five were derived from Ae. tauschii. The cloned leaf rust resistance gene Lr21 (Huang et al. 2003) was first made available in a synthetic line RL5406 (Rowland and Kerber 1974; McIntosh et al. 1995) before being backcrossed in cultivar Thatcher and other genotypes. Introgression of genes $\mathrm{Lr} 22 \mathrm{a}$ (Rowland and Kerber 1974) and Lr32 (Kerber 1987) was achieved in a similar way, whereas $L r 39$ (Raupp et al. 2001) and Lr42 (Cox et al. 1993) were transferred by direct hybridisation with common wheat and embryo rescue from the $\mathrm{F}_{1}$ hybrids (Gill and Raupp 1987). Previously designated genes $L r 40$ and $L r 41$ were shown to be $L r 21$ and $L r 39$, respectively, whereas wheat stock WGRC16 reported to have Lr43 carried gene 
combination $L r 21$ and $L r 39$ (Gill et al. 2008). Therefore, these gene designations were deleted from the Catalogue of Gene Symbols for Wheat (McIntosh et al. 2013).

In the present study, we used both traditional and molecular genetic approaches to investigate the genetic basis of resistance to leaf rust in the synthetic hexaploid wheat line Syn 137 .

\section{Materials and methods}

\section{Plant materials and genetic analysis}

Syn137 (68.111/RGB-U//Ward/3/Ae. tauschii (WX629)), a leaf rust resistant entry in the CIMMYT 1 st $\mathrm{AB} \times \mathrm{D}$ Elite Synthetics Programme, was crossed with each of the 21 Chinese Spring (CS) monosomic lines originally developed by, and obtained from, E.R. Sears, University of Missouri, USA. Cytologically confirmed monosomic $\mathrm{F}_{1}$ plants were grown in the greenhouse to obtain $F_{2}$ seeds. The location of genes by monosomic analysis depends on the identification of an abnormal genetic ratio in one cross (the 'critical' cross) in which the resistance gene is located on the non-pairing monosomic chromosome, compared with normal disomic inheritance of the resistance gene in the 20 'non-critical' crosses. To confirm $\mathrm{F}_{2}$ segregation of the critical cross, $\mathrm{F}_{2: 3}$ lines ( 34 plants each) of 20 resistant $F_{2}$ plants were assessed for response to leaf rust. A total of $93 \mathrm{~F}_{2: 3}$ lines originating from the disomic cross between CS and Syn137 were used to analyse linkage between molecular markers and the resistance gene. Chi-squared tests for goodness of fit were used to test for deviation of observed data from theoretically expected segregation ratios. Chi-squared values were corrected for continuity (http://vassarstats.net/csfit.html). A test of allelism between the gene in Syn 137 and Lrl in the Thatcher derivative RL 6003 involved $54 \mathrm{~F}_{2: 3}$ lines (24 to 30 seedlings each) and deployed rust isolates S12 (avirulent to both resistance genes) and Pt60 (virulent to $L r 1$ and avirulent to the gene in Syn137). A Chi-squared test of independence using a genetic ratio of 11 (homozygous resistant + segregating 15:1): 2 (segregating 3:1, resistant to both isolates): 2 (segregating 3:1 to one isolate, homozygous susceptible to the other): 1 (homozygous susceptible) was applied to assess linkage of the two resistance genes. A set of 13 single-gene lines with known leaf rust resistance genes was used to compare leaf rust responses to Syn137.

\section{Leaf rust reaction tests}

Disease testing was carried out on primary leaves of 10-day old host seedlings according to the method of Felsenstein et al. (1998). The 3-cm-leaf segments were cultured in clear polystyrene boxes on $6 \mathrm{~g} / \mathrm{l}$ agar and $35 \mathrm{mg} / \mathrm{l}$ benzimidazole. The experiments used $P t$ isolates derived from single spores, most of which were collected in Europe. Pt isolate Race 9 was originally provided by P.L. Dyck, Winnipeg, Canada. Inoculum was produced on the susceptible wheat cultivar Kanzler, collected and dispersed above the exposed leaves in a settling tower at densities of $400-500$ spores $/ \mathrm{cm}^{2}$. Plates with inoculated leaf segments were wrapped in paper towel wetted with distilled water, and then enclosed in black plastic for $24 \mathrm{~h}$. The leaf segment boxes were maintained under continuous light in a growth chamber at $17{ }^{\circ} \mathrm{C}$ and at $60-80 \%$ relative humidity. Disease response was measured 10 days after inoculation and followed the 0-4 infection type (IT) scoring system, in which IT ' 0 ' indicated no visible symptoms. IT ';' indicated hypersensitive flecks; IT ' 1 ' indicated small uredinia with necrosis; IT ' 2 ' indicated small to medium-sized uredinia with green islands and surrounded by necrosis or chlorosis; IT ' 3 ' indicated medium to large-sized uredinia with chlorosis; IT ' 4 ' indicated large uredinia without chlorosis and IT ' $\mathrm{X}$ ' indicated heterogeneous ITs, similarly distributed over a given leaf. Plus and minus signs were used to indicate higher and lower response than average for a given IT. Infection types ' 3 ' or higher were regarded as compatible (high IT), whereas ITs of '2' or lower were regarded as incompatible (low IT).

\section{Molecular mapping}

Bulked segregant analysis (Michelmore et al. 1991) was used to identify microsatellite marker loci from wheat chromosome 5D with linkage to the gene in Syn137. Resistant and susceptible bulks consisted of DNA from eight homozygous resistant and eight homozygous susceptible $\mathrm{F}_{2: 3}$ lines of the $\mathrm{CS} \times$ Syn137 mapping population. Fifteen individuals of each $\mathrm{F}_{2: 3}$ line were collected for DNA extraction (Huang et al. 2000b). Analysis of microsatellite markers from chromosome 5D was carried out as described in Huang et al. (2000a). Primer information and PCR conditions for the Lrl-specific marker RGA567-5 were taken from Cloutier et al. (2007). Following segregation analysis of leaf rust response, 5 microsatellite markers, and RGA567-5 in the mapping population, a partial linkage map was computed with the program JoinMap 5.0. Map distances were calculated using the Haldane function. Charts of genetic linkage maps were drawn with the computer program MapChart 2.1 (Voorrips 2002).

\section{Results}

\section{Leaf rust response}

The IT response pattern of Syn 137 to $9 P t$ isolates was different to those obtained for the 13 reference genotypes (Table 1). The resistance gene in Syn137 was characterised by low ITs to all $P t$ cultures ranging from ' 0 ;' to ' $; 2=$ '. 
Table 1 Leaf rust infection types produced by wheat cultivars/lines possessing known leaf rust resistance genes and Syn137 after inoculation with nine $P t$ isolates

\begin{tabular}{lllllllllll}
\hline Line & \multicolumn{1}{l}{ Pt isolate } & & & & & & & & \multirow{2}{*}{ Gene } \\
\cline { 2 - 8 } & $\mathrm{S} 12$ & $\mathrm{~S} 28$ & $\mathrm{~S} 29$ & $\mathrm{~S} 48$ & $\mathrm{~S} 71$ & $\mathrm{Pt8}$ & $\mathrm{Pt9}$ & $\mathrm{Pt60}$ & Race 9 & \\
\hline Syn137 & $; 1$ & $; 1$ & $; 1=$ & $12=$ & $; 2=$ & $;$ & $; 1$ & $0 ;$ & $0 ;$ & LrSyn137 \\
RL 6003 & $0 ;$ & 1 & $0 ;$ & $0 ;$ & $0 ;$ & $0 ;$ & $0 ;$ & $3++$ & $0 ;$ & Lr1 \\
RL 6016 & $;$ & 12 & $;$ & $;$ & $;$ & 1 & 1 & $3++$ & 2 & Lr2a \\
Democrat & 2 & $2+$ & 3 & 3 & 1 & $\mathrm{X}+$ & 3 & $;$ & 12 & Lr3a \\
Klein Aniversario & 2 & 2 & 3 & $3=$ & 3 & $;$ & 3 & 1 & 3 & Lr3c \\
RL 6010 & $0 ;$ & 2 & $0 ;$ & $0 ;$ & $0 ;$ & $0 ;$ & $0 ;$ & $3=$ & $0 ;$ & Lr9 \\
Kenya 1-12E-19J & 4 & $; 1$ & 3 & 2 & 3 & $\mathrm{X}$ & 3 & 4 & 4 & Lr15 \\
Exchange & 4 & 4 & 2 & 3 & $\mathrm{X}$ & 2 & 3 & $\mathrm{X}$ & 4 & Lr16 \\
Agatha & $0 ;$ & $0 ;$ & $0 ;$ & $0 ;$ & $0 ;$ & $0 ;$ & $0 ;$ & $0 ;$ & $0 ;$ & Lr19 \\
Thew & 3 & 2 & 0 & 3 & 3 & 2 & 3 & 4 & 3 & Lr20 \\
RL 5289 & 3 & 2 & 3 & 3 & 1 & $3++$ & 3 & 12 & 3 & Lr21 \\
Agent & $;$ & $; 1$ & $;$ & $;$ & $;$ & 1 & 1 & 1 & 1 & Lr24 \\
Disponent & $3++$ & 1 & $;$ & 2 & $0 ;$ & 3 & 4 & 12 & 2 & Lr26 \\
RL 6049 & 3 & 1 & 1 & 3 & 3 & 2 & 2 & $; 1$ & 2 & Lr30 \\
\hline
\end{tabular}

${ }^{1}$ Registered accessions of Agriculture Canada Research Station, Winnipeg

\section{Monosomic analysis}

$\mathrm{F}_{2}$ populations from the monosomic $\mathrm{F}_{1}$ hybrids were tested with $P t$ isolate $\mathrm{S} 12$. Segregation in all crosses, except that involving chromosome 5D, corresponded to that expected for 3 resistant: 1 susceptible, indicating a single dominant gene for resistance (Table 2). Segregation in the 5D cross deviated significantly from $3: 1\left(\chi_{3: 1}^{2}=21.49, P<0.0001\right.$, $\mathrm{df}=1$ ), with only 1 of 76 seedlings scored as susceptible. In this critical cross, it was expected that the disomics (RR) and monosomics $(\mathrm{R}-)$ were resistant, whereas the nullisomics $(-)$ were susceptible. Hence, it is assumed that the susceptible plant was a nullisomic indicating that the resistance gene was located on chromosome 5D. In addition, $20 \mathrm{~F}_{3}$ lines derived from randomly selected resistant $\mathrm{F}_{2}$ plants of the critical cross were progeny tested. It has been well documented that the accuracy of individual $\mathrm{F}_{2}$ plant classification can be established on the basis of progeny testing. Where a single chromosome conferring resistance is involved, $\mathrm{F}_{2}$ progenies of non-critical crosses segregate 1 resistant: 2 segregating: 1 susceptible, while the progeny of a critical cross should have a reduced number of the latter (McIntosh 1987). In the present result, none of the $F_{2}$ progeny showed a 1:2:1 segregation confirming that the resistance gene is located on chromosome $5 \mathrm{D}$.

\section{Genetic mapping}

Assuming single-gene segregation, the $\mathrm{F}_{3}$ population of cross CS $\times$ Syn 137 displayed distorted segregation when tested with isolates S12 and Race 9 (26 homozygous resistant: 61 heterozygous: 6 susceptible; $\chi_{1: 2: 1}^{2}=17.65, P=0.0001, \mathrm{df}=$
2). Based on the results of monosomic analysis, microsatellite markers evenly distributed across chromosome 5D were used for molecular analysis. The five microsatellite marker loci Xbarc177, Xgwm269, Xgwm272, Xgwm565, and Xgwm654 from the long arm of chromosome 5D were polymorphic in bulked segregant analysis. Linkage analysis of phenotypic and molecular data in $93 \mathrm{~F}_{2: 3}$ lines from $\mathrm{CS} \times \mathrm{Syn} 137$ refined location of the resistance gene distal to Xgwm272 (Fig. 1). As the dominant leaf rust resistance gene $L r l$ is also known to be located on chromosome 5DL, marker RGA567-5 functional for $\operatorname{Lrl}$ was assayed on the parental lines. Syn137 showed amplification of the RGA567-5 marker fragment, whereas CS was null. Segregation analysis across the population showed that the $L r l$-specific marker mapped $5.4 \mathrm{cM}$ proximal to the studied resistance locus (Fig. 1). The new leaf rust resistance gene was temporarily designated $\operatorname{LrSyn} 137$. As observed for the studied phenotype, all marker loci deviated significantly from Mendelian expectations (Table 3). While all loci showed a deficiency of CS - the female parent-homozygotes, LrSyn 137 showed an excess of heterozygotes, and the molecular marker loci were skewed towards homozygous Syn137 genotypes.

\section{Test of allelism}

A test of allelism was conducted between $\mathrm{LrSyn} 137$ and $\mathrm{Lrl}$. The $54 \mathrm{~F}_{3}$ progeny scores for $P t$ isolate $\mathrm{S} 12$, to which both genes showed resistance (Table 1), conformed to a digenic dominant 15:1 ratio (53 resistant/segregating and 1 susceptible $\mathrm{F}_{3}$ families; $\left.\chi_{15: 1}^{2}=1.11, P=0.29, \mathrm{df}=1\right)$. For $P t$ isolate Pt60, which was virulent to $L r 1$ but avirulent to $L r S y n 137$ (Table 1), a segregation ratio of 3:1 (42 resistant and 12 
Table $2 \quad \mathrm{~F}_{2}$ segregation for seedling reaction to $P t$ isolate $\mathrm{S} 12$ in progenies of monosomic $\mathrm{F}_{1}$ plants from crosses between Chinese Spring monosomics and Syn 137

\begin{tabular}{|c|c|c|c|c|}
\hline \multirow[t]{2}{*}{ Monosomic cross } & \multicolumn{2}{|c|}{ Observed segregation } & \multirow[t]{2}{*}{$\chi_{3: 1}^{2}$} & \multirow[t]{2}{*}{$P$} \\
\hline & Resistant & Susceptible & & \\
\hline $1 \mathrm{~A} \times$ Syn 137 & 64 & 15 & 1.21 & 0.2713 \\
\hline $2 \mathrm{~A} \times \operatorname{Syn} 137$ & 37 & 11 & 0.03 & 0.8625 \\
\hline $3 \mathrm{~A} \times$ Syn 137 & 63 & 19 & 0.07 & 0.7913 \\
\hline $4 \mathrm{~A} \times \operatorname{Syn} 137$ & 70 & 21 & 0.09 & 0.7642 \\
\hline $5 \mathrm{~A} \times \operatorname{Syn} 137$ & 67 & 25 & 0.13 & 0.7184 \\
\hline $6 \mathrm{~A} \times \operatorname{Syn} 137$ & 70 & 19 & 0.45 & 0.5023 \\
\hline $7 \mathrm{~A} \times$ Syn 137 & 71 & 17 & 1.23 & 0.2674 \\
\hline $1 \mathrm{~B} \times$ Syn 137 & 58 & 24 & 0.59 & 0.4424 \\
\hline $2 \mathrm{~B} \times \operatorname{Syn} 137$ & 59 & 15 & 0.65 & 0.4201 \\
\hline $3 \mathrm{~B} \times$ Syn 137 & 55 & 25 & 1.35 & 0.2453 \\
\hline 4B $\times$ Syn 137 & 77 & 17 & 2.04 & 0.1532 \\
\hline $5 B \times$ Syn 137 & 68 & 20 & 0.13 & 0.7184 \\
\hline $6 \mathrm{~B} \times$ Syn 137 & 65 & 20 & 0.04 & 0.8415 \\
\hline 7B $\times$ Syn 137 & 61 & 24 & 0.32 & 0.5716 \\
\hline $1 \mathrm{D} \times \operatorname{Syn} 137$ & 73 & 18 & 1.05 & 0.3055 \\
\hline $2 \mathrm{D} \times \operatorname{Syn} 137$ & 69 & 23 & 0.01 & 1.0000 \\
\hline $3 \mathrm{D} \times \operatorname{Syn} 137$ & 63 & 24 & 0.19 & 0.6629 \\
\hline $4 \mathrm{D} \times \operatorname{Syn} 137$ & 60 & 18 & 0.07 & 0.7913 \\
\hline $5 \mathrm{D} \times \operatorname{Syn} 137$ & 75 & 1 & 21.49 & $<0.0001$ \\
\hline $6 \mathrm{D} \times$ Syn 137 & 63 & 18 & 0.20 & 0.6547 \\
\hline 7D $\times$ Syn 137 & 67 & 22 & 0.00 & 1.0000 \\
\hline Total excluding 5D & 1280 & 395 & 1.72 & 0.1897 \\
\hline
\end{tabular}

susceptible $\mathrm{F}_{3}$ families; $\chi_{3: 1}^{2}=0.22, P=0.76, \mathrm{df}=1$ ) was obtained. This result clearly showed that $\operatorname{LrSyn} 137$ is inherited in a dominant manner. Combining results from both isolates, 18 families were identified as either homozygous resistant or segregating 15:1 (resistant: susceptible). Twenty-five families showed a $3: 1$, resistant to susceptible, segregation pattern to $P t$ isolate $\mathrm{S} 12$, to which both wheat lines showed resistance. Another 10 families segregated into 3 resistant: 1 susceptible to $P t$ isolate $\mathrm{S} 12$, but these families were concurrently susceptible to $P t$ isolate Pt60. One family was homozygous susceptible to both $P t$ isolates. A Chi-squared test of independence of the pooled data indicated that the two resistance loci were linked $\left(\chi_{11: 2: 2: 1}^{2}=62.43, P<0.0001, \mathrm{df}=3\right)$.

\section{Discussion}

Cytogenetic and linkage mapping located a dominant leaf rust resistance gene in Syn 137 on chromosome 5D. In the course of determining the identity of the resistance gene on chromosome 5DL, a functional marker for $L r l$ was given priority to be assayed on the mapping population. The $L r l$-specific

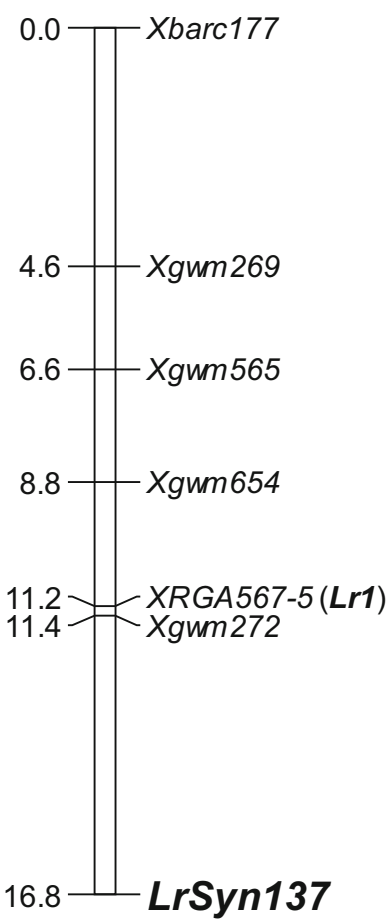

Fig. 1 Linkage map of the distal part of wheat chromosome 5DL including leaf rust resistance gene $\mathrm{LrSyn} 137$. Absolute map positions in $\mathrm{cM}$, and marker names are shown on the left and right, respectively, of the genetic map

marker RGA567-5 was found to map proximal to $\operatorname{LrSyn} 137$ indicating distinctiveness of LrSyn 137 from $\mathrm{Lr} 1$. In addition, we could confirm the close linkage of RGA567-5, and thus $\mathrm{Lr} 1$, proximal to microsatellite marker locus Xgwm272 (Ling et al. 2003). Despite a limited number of progeny, a genetic test of allelism between $\mathrm{Lrl}$ and $\mathrm{LrSyn} 137$ further supported that the two genes are linked to each other. The study provides a good basis for the development of single nucleotide polymorphism-based kompetitive allele specific PCR markers for marker-assisted selection of LrSyn 137.

The experiments conducted, however, suggested that Syn 137 is heterogeneous for resistance gene $L r 1$. However, heterogeneity for $\mathrm{Lrl}$ seems to be rare as only the line that was used for establishing the mapping population seemed to have carried $L r 1$; besides the successful allelic cross, all non-critical monosomic crosses- $P t$ isolate $\mathrm{S} 12$ was avirulent to both $\operatorname{LrSyn} 137$ and $\operatorname{Lrl}-$ showed single-gene segregation. The mapping population showed segregation distortion of all loci on chromosome 5DL. Therefore, it appears that compared to lines possessing only $\operatorname{LrSyn} 137$, the line carrying both LrSyn 137 and Lrl, additionally carries genes on chromosome 5DL generating a distortion in normal segregation in favour of themselves. Similar to our observations, Faris et al. (1998) and $\mathrm{Li}$ et al. (2015) reported distorter loci in Ae. tauschii and common wheat, respectively, located in the same genomic region on chromosome 5DL. 
Table 3 Locus genotype frequencies in the CS $\times$ Syn137 mapping population

\begin{tabular}{llllllllll}
\hline Locus & Position cM & $a$ & $h$ & $b$ & $c$ & - & $\chi^{2}$ & $P$ & df \\
\hline Xbarc177 & 0 & 14 & 44 & 35 & 0 & 0 & 9.75 & 0.0076 & 2 \\
Xgwm269 & 4.6 & 10 & 50 & 33 & 0 & 0 & 11.9 & 0.0026 & 2 \\
Xgwm565 & 6.6 & 10 & 50 & 32 & 0 & 1 & 11.22 & 0.0037 & 2 \\
Xgwm654 & 8.8 & 12 & 45 & 36 & 0 & 0 & 12.48 & 0.0019 & 2 \\
XRGA567-5 & 11.2 & 6 & 0 & 0 & 87 & 0 & 16.09 & $<0.0001$ & 1 \\
Xgwm272 & 11.4 & 6 & 47 & 40 & 0 & 0 & 24.87 & $<0.0001$ & 2 \\
LrSyn137 $_{\text {Xxpected }}$ & 16.8 & 6 & 61 & 26 & 0 & 0 & 17.65 & 0.0001 & 2 \\
Expected $_{3: 1}$ & & 23.25 & 46.5 & 23.25 & & & & & \\
\hline
\end{tabular}

$a$, homozygous Chines Spring genotype

$b$, homozygous Syn137 genotype

$h$, heterozygous

$c$, not genotype a (allele $\mathrm{b}$ is dominant)

$d f$, degree of freedom
Three formally designated genes were located on chromosome 5D: $L r l$, shown to be available in many wheat cultivars (McIntosh et al. 1995) and Ae. tauschii accessions (e.g., Ling et al. 2004), Lr57 from Ae. geniculata (Kuraparthy et al. 2007), and $L r 70$ from common wheat (Hiebert et al. 2014), of which the latter two were assigned to the short arm of chromosome 5D. Qi et al. (2015) described leaf rust resistance gene $\operatorname{Lr} L B 88$ on chromosome 5DL that co-segregated with $L r l$ but showed a reaction pattern to 13 Chinese $P t$ pathotypes that was clearly distinct to Lr1. Whether $\operatorname{LrSyn} 137$ and $L r L B 88$ are independent genes or $L r L B 88$ is an allele or closely linked to $L r l$ needs to be determined in follow-up research. However, satisfactory evidence is presented, similar to powdery mildew (Miranda et al. 2006, 2007), that diverse leaf rust resistance genes are located in the terminal region of chromosome 5DL.

Synthetic hexaploid wheats were mainly used for the transfer of genes controlling resistance to biotic stress because of their mostly simple inheritance and ease of detection, but they have also emerged as a valuable resource for enhancing tolerance to abiotic stresses, nutritional value, and grain quality attributes (van Ginkel and Ogbonnaya 2007; Li et al. 2018). However, new avenues must be taken for increasing allele diversity and recombination in structured populations to exploit the wealth of information available in synthetic wheats. Therefore, population types such as the multiparent advanced generation intercross (Cavanagh et al. 2008) or multiple synthetic derivatives (Gorafi et al. 2018) will support introgression breeding and accelerate gene discovery.

Acknowledgements Open Access funding provided by Projekt DEAL.

Author contributions VM and SLKH conceived the research. SLKH and FJZ performed cytogenetic mapping and allelism test. VM and MS performed marker analysis and molecular mapping. VM and SLKH drafted the manuscript and MS and FJZ commented on it.

\section{Compliance with ethical standards}

Conflict of interest The authors declare that they have no conflicts of interest.

Ethical approval This article does not contain any studies with human participants or animals performed by any of the authors.

Open Access This article is licensed under a Creative Commons Attribution 4.0 International License, which permits use, sharing, adaptation, distribution and reproduction in any medium or format, as long as you give appropriate credit to the original author(s) and the source, provide a link to the Creative Commons licence, and indicate if changes were made. The images or other third party material in this article are included in the article's Creative Commons licence, unless indicated otherwise in a credit line to the material. If material is not included in the article's Creative Commons licence and your intended use is not permitted by statutory regulation or exceeds the permitted use, you will need to obtain permission directly from the copyright holder. To view a copy of this licence, visit http://creativecommons.org/licenses/by/4.0/.

\section{References}

Burdon JJ, Barrett LG, Rebetzke G, Thrall PH (2014) Guiding deployment of resistance in cereals using evolutionary principles. Evol Appl 7:609-624. https://doi.org/10.1111/eva.12175

Cavanagh C, Morell M, Mackay I, Powell W (2008) From mutations to MAGIC: resources for gene discovery, validation and delivery in crop plants. Curr Opin Plant Biol 11:215-221. https://doi.org/10. 1016/j.pbi.2008.01.002

Cloutier S, McCallum BD, Loutre C, Banks TW, Wicker T, Feuillet C, Keller B, Jordan MC (2007) Leaf rust resistance gene Lrl, isolated from bread wheat (Triticum aestivum L.) is a member of the large psr567 gene family. Plant Mol Biol 65:93-106. https://doi.org/10. 1007/s11103-007-9201-8

Cox TS, Raupp WJ, Gill BS (1993) Leaf rust-resistance genes $L r 41$, Lr42 and Lr43 transferred from Triticum tauschii to common wheat. Crop 
Sci 34:339-343. https://doi.org/10.2135/cropsci1994. 0011183X003400020005x

Faris JD, Laddomada B, Gill BS (1998) Molecular mapping of segregation distortion loci in Aegilops tauschii. Genetics 149:319-327

Felsenstein FG, Park RF, Zeller FJ (1998) The use of detached seedling leaves of Triticum aestivum to study pathogenicity in Puccinia recondita f.sp. tritici. J Phytopathol 146:115-121. https://doi.org/ 10.1111/j.1439-0434.1998.tb04667.x

Gill BS, Raupp WJ (1987) Direct genetic transfers from Aegilops squarrosa L. to hexaploid wheat. Crop Sci 27:445-450. https:// doi.org/10.2135/cropsci1987.0011183X002700030004x

Gill BS, Huang L, Kuraparthy V, Raupp WJ, Wilson DL, Friebe B (2008) Alien genetic resources for wheat leaf rust resistance, cytogenetic transfer, and molecular analysis. Aust J Agric Res 59:197-205. https://doi.org/10.1071/AR07315

Gorafi YSA, Kim JS, Elbashir AAE, Tsujimoto H (2018) A population of wheat multiple synthetic derivatives: an effective platform to explore, harness and utilize genetic diversity of Aegilops tauschii for wheat improvement. Theor Appl Genet 131:1615-1626. https://doi. org/10.1007/s00122-018-3102-x

Hiebert CW, McCallum BD, Thomas JB (2014) $L r 70$, a new gene for leaf rust resistance mapped in common wheat accession KU3198. Theor Appl Genet 127:2005-2009. https://doi.org/10.1007/s00122-0142356-1

Huang XQ, Hsam SLK, Zeller FJ, Wenzel G, Mohler V (2000a) Molecular mapping of the wheat powdery mildew resistance gene Pm24 and marker validation for molecular breeding. Theor Appl Genet 101:407-414. https://doi.org/10.1007/s001220051497

Huang XQ, Zeller FJ, Hsam SLK, Wenzel G, Mohler V (2000b) Chromosomal location of AFLP markers in common wheat utilizing nulli-tetrasomic stocks. Genome 43:298-305. https://doi.org/10. 1139/gen-43-2-298

Huang L, Brooks SA, Li W, Fellers JP, Trick HN, Gill BS (2003) Mapbased cloning of leaf rust resistance gene $\operatorname{Lr} 21$ from the large and polyploid genome of bread wheat. Genetics 164:655-664

Kerber ER (1987) Resistance to leaf rust in hexaploid wheat, Lr32, a third gene derived from Triticum tauschii. Crop Sci 27:204-206. https:// doi.org/10.2135/cropsci1987.0011183X002700020013x

Kuraparthy V, Chhuneja P, Dhaliwal HS, Kaur S, Bowden RL, Gill BS (2007) Characterization and mapping of cryptic alien introgression from Aegilops geniculata with new leaf rust and stripe rust resistance genes Lr57 and Yr40 in wheat. Theor Appl Genet 114:13791389. https://doi.org/10.1007/s00122-007-0524-2

Li C, Bai G, Chao S, Wang Z (2015) A high-density SNP and SSR consensus map reveals segregation distortion regions in wheat. Biomed Res Int. https://doi.org/10.1155/2015/830618

Li A, Liu D, Yang W, Kishii M, Mao L (2018) Synthetic hexaploid wheat: yesterday, today, and tomorrow. Engineering 4:552-558. https://doi. org/10.1016/j.eng.2018.07.001

Ling HQ, Zhu Y, Keller B (2003) High-resolution mapping of the leaf rust disease resistance gene $\mathrm{Lrl}$ in wheat and characterization of BAC clones from the $L r 1$ locus. Theor Appl Genet 106:875-882. https:// doi.org/10.1007/s00122-002-1139-2

Ling HQ, Qiu JW, Singh RP, Keller B (2004) Identification and genetic characterization of an Aegilops tauschii ortholog of the wheat leaf rust disease resistance gene $\mathrm{Lrl}$. Theor Appl Genet 109:1133-1138. https://doi.org/10.1007/s00122-004-1734-5

McIntosh RA (1987) Gene location and gene mapping in hexaploid wheat. In: Heyne EG (ed) Wheat and wheat improvement.
Agronomy monograph no 13 , 2nd edn. ASA/CSSA/SSSA, Madison, pp 269-287

McIntosh RA, Dubcovsky J, Rogers WJ, Morris C, Xia XC (2017) Catalogue of gene symbols for wheat: 2017 supplement. https:// shigen.nig.ac.jp/wheat/komugi/genes/macgene/supplement2017. pdf. Accessed 13 December 2019

McIntosh RA, Wellings CR, Park RF (1995) Wheat rusts: an atlas of resistance genes. CSIRO Publications, Melbourne

McIntosh RA, Yamazaki Y, Dubcovsky J, Rogers J, Morris C, Appels R, Xia XC (2013) Catalogue of gene symbols for wheat. http://www. shigen.nig.ac.jp/wheat/komugi/genes/macgene/2013/GeneSymbol. pdf. Accessed 20 October 2019

Michelmore RW, Paran I, Kesseli RV (1991) Identification of markers linked to disease-resistance genes by bulked segregant analysis: a rapid method to detect markers in specific genomic regions by using segregating populations. Proc Natl Acad Sci U S A 88:9828-9832. https://doi.org/10.1073/pnas.88.21.9828

Miranda LM, Murphy JP, Marshall D, Leath S (2006) Pm34: a new powdery mildew resistance gene transferred from Aegilops tauschii Coss. to common wheat (Triticum aestivum L.). Theor Appl Genet 113:1497-1504. https://doi.org/10.1007/s00122-006-0397-9

Miranda LM, Murphy JP, Marshall D, Cowger C, Leath S (2007) Chromosomal location of Pm35, a novel Aegilops tauschii derived powdery mildew resistance gene introgressed into common wheat (Triticum aestivum L.). Theor Appl Genet 114:1451-1456. https:// doi.org/10.1007/s00122-007-0530-4

Qi A, Li X, Shi L, Li Z (2015) Identification of a leaf rust resistance gene in the Chinese wheat line LB0288. Czech J Genet Plant Breed 51: 43-49. https://doi.org/10.17221/2/2015-CJGPB

Qureshi N, Bariana H, Kumran VV, Muruga S, Forrest KL, Hayden MJ, Bansal U (2018) A new leaf rust resistance gene Lr79 mapped in chromosome 3BL from the durum wheat landrace Aus26582. Theor Appl Genet 131:1091-1098. https://doi.org/10.1007/s00122-0183060-3

Raupp WJ, Singh S, Brown-Guedira GL, Gill BS (2001) Cytogenetic and molecular mapping of the leaf rust resistance gene Lr39 in wheat. Theor Appl Genet 102:347-352. https://doi.org/10.1007/ s001220051652

Rowland GC, Kerber ER (1974) Telocentric mapping in hexaploid wheat of genes for leaf rust resistance and other characters derived from Aegilops squarrosa. Can J Genet Cytol 16:137-144. https://doi.org/ $10.1139 / \mathrm{g} 74-013$

van Ginkel M, Ogbonnaya F (2007) Novel genetic diversity from synthetic wheats in breeding cultivars for changing production conditions. Field Crop Res 104:86-94. https://doi.org/10.1016/j.fcr.2007. 02.005

Voorrips RE (2002) MapChart: software for the graphical presentation of linkage maps and QTLs. J Heredity 93:77-78. https://doi.org/10. 1093/jhered/93.1.77

A pre-print version of the article can be accessed at https://www.biorxiv. org/content/10.1101/721415v1.

Publisher's note Springer Nature remains neutral with regard to jurisdictional claims in published maps and institutional affiliations. 